\title{
PLURAlitas agama dalam PERSPEKTIF PERMAINAN Dialog Antaragama dalam Hermenutika HG Gadamer
}

\author{
Oleh: Happy Susanto*
}

Abstract

The writer tries to analyze the problem of religious plurality through HG Gadamer's hermeneutical analysis. In the article, the writer starts his analysis from the phenomenon of interreligious relationship happens in the world. In the writer's opinion-based on HG Gadamer's analysis-, that human look lost in the phenomenon of hard interreligious relation, on contrary it suggests that the interdependent among religious people. The two categories above don't mean the relation of win or loss, or domination relation, but it is better to say "belonging relation". Moreover the writer specifies that communicative attitude for knowing the others which together with knowing himself could solve all problems of interreligious relationship with some consensus obtained without any pressure. Knowing the others doesn't mean following other's attitude, but influencing or influenced. Thus, the critical and innovative attitude are needed. Life is just a game.

\section{الحلامة}

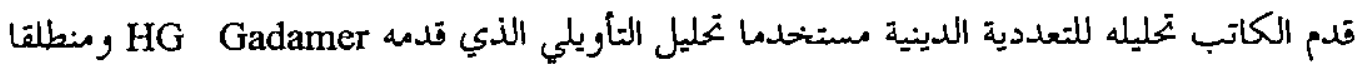

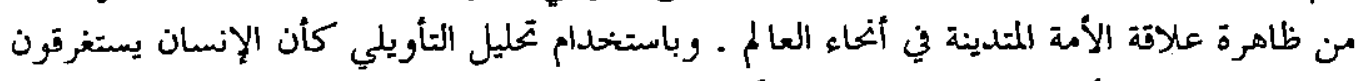

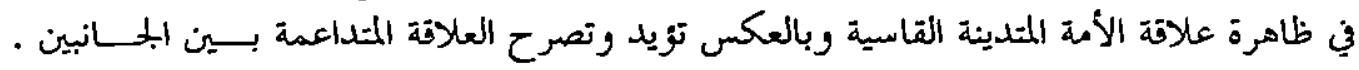

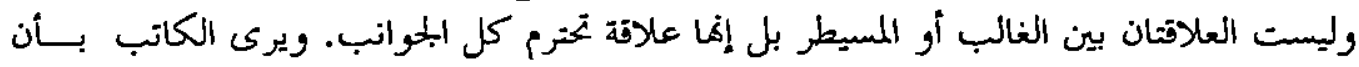

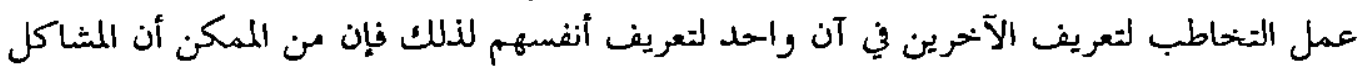

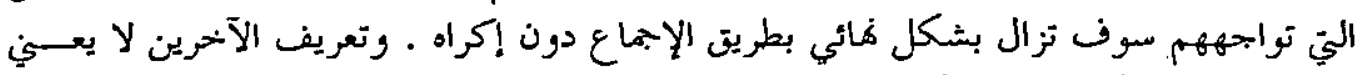

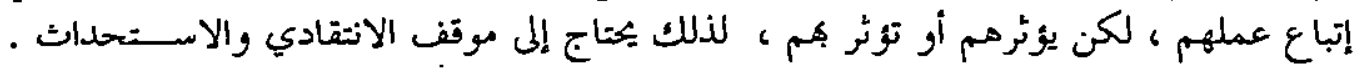

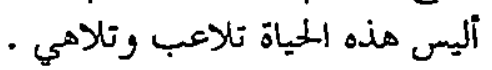

Kata Kunci: Pluralitas, Agama, Permainan

"Staf Pengajar Institut Studi Islam Darussalam (ISID) Gontor Ponorogo dan alumni Ilmu perbandingan Agama (Agama dan Lintas Budaya) Yogyakarta. 


\section{A. Pendahuluan}

aat ini pluralitas agama adalah sebuah keniscayaan. Orang tidak bisa lagi menutup - mata atau pura-pura tidak tahu, bahwa di sekitarnya terdapat berbagai macam bentuk masyarakat, agama, dan kebudayaan. Namun kesadaran akan keberagaman ini juga bukan persoalan yang mudah terutama pada persolan agama. Salah satu masalah yang serius dihadapi bangsa ini adalah makin menguatnya sentimen-sentimen keagamaan.

Terjadinya banyak pertikaian yang bersumber dari "agama" merupakan pekerjaan rumah yang belum terselesaikan hingga kini. Masih hangat di telinga kita pertikaian antara Palestina dan Israel, persaingan antara Kristen dan Islam di Afrika, pertikaian umat Hindu dengan Islam di India. Perbedaan cara pandang agama juga membawa persoalan tersendiri. Masih ingat kita perdebatan antara kelompok modernis yang diwakili oleh Nurcholis Madjid dengan kelompok "fundamentalis" Daud Rasyid dkk, fatwa mati kepada Ulil Abshar Abdala "JL" dari Kiai Athian (Forum Ulama Umat Islam Indonesia), konflik Poso, dan Ambon, yang menewaskan puluhan orang. Serta masih banyak lagi contoh jertikaian yang bersumberkan SARA di Indonesia. Hal di atas menunjukkan bahwa agama mempunyai peran yang cukup besar dalam membentuk prilaku manusia dan untuk menciptakan peradabannya.

\section{B. Kesalahan Teori Sekularisasi}

Fenomena di atas menunjukkan dengan tegas bahwa tesis dunia ini telah tersekulerkan dengan sendirinya terbantah. Untuk itu Peter L. Berger menyatakan bahwa asumsi kita selama ini hidup dalam abad sekularisasi adalah asumsi yang palsu. Sebaliknya dunia ini diwarnai oleh rasa keagamaan yang semakin kuat. Modernisasi yang diwarnai dengan ide-ide sekuler dan mendominasi pemikiran para ilmuan-ilmuan sosial dan sejarah tidak serta merta menghilangkan pengaruh agama dalam masyarakat.

Istilah "sekularisasi" merujuk pada tulisan tahun 1950-an dan 1960-an, yang ide pokok teori ini sebenarnya dapat dilacak pada masa pencerahan. Ide yang dilontarkan sebenarnya adalah sederhana bahwa modernisasi biasanya membawa pada mundurnya agama, baik pada masyarakat atau dalam pikiran seseorang. Dan memang modernisasi memiliki beberapa efek sekularisasi di beberapa tempat. Akan tetapi sekularisasi juga mendorong kekuatan gerakan-gerakan anti-sekularisasi.

Sekularisasi dalam level masyarakat tidak selalu dihubungkan pada sekulerisasi pada level kesadaran individu. Mungkin saja institusi keagamaan telah kehilangan kekuatan dan pengaruhnya dalam beberapa masyarakat, baik kepercayaan dan praktek agama yang lama ataupun baru, akan tetapi bisa saja masih berlangsung dalam kehidupan individual, kadang-kadang menjadi bentuk intitusi baru dan kadang-kadang membawa pada ledakan besar gairah keagamaan.

Sebaliknya, institusi yang beridentitas agama dapat bermain pada aturan sosial atau politik meski masyarakatnya sangat sedikit yang percaya dan menjalankan agama 
dalam institusi-institusi yang hadir tersebut. ${ }^{1}$ Harus diakui bahwa agama masih merupakan faktor yang cukup efektif untuk memobilisasi massa dalam dunia politik. Hal ini dapat kita lihat dalam pemilu kita kemarin, meski politik "santri" cenderung menurun namun masih banyak partai yang menggunakan basis agama sebagai kekuatan.

Memang hubungan agama dan modernitas agak kompleks. Proposisi bahwa modernitas yang bebas nilai biasanya membawa pada mundurnya agama. Kebanyakan pemikir pencerahan dan kebanyakan masyarakat berpikiran progresif selalu mempunyai pandangan bahwa ide sekularisasi adalah sesuatu yang bagus, paling tidak sekulerisasi adalah cara dimana fenomena takhayyul atau "reaksioner" keagamaan dan karakteristik negatif agama dapat dikurangi. Akan tetapi masyarakat agama, termasuk mereka yang sangat tradisional dan ortodok, memandangnya negatifdan mendefinisikannya sebagai musuh yang harus diperangi. Sedangkan yang lain sebaliknya, melihat modemitas sebagai semacam pandangan dunia yang tak nampak yang mana praktek dan keyakinan agama mereka sendiri harus menyesuaikannya. Dengan kata lain, penolakan dan penyesuaian adalah dua strategi terbuka bagi komunitas agama di dunia yang dianggap telah sekuler. ${ }^{2}$

Berger sendiri yang dulunya mendukung teori di atas sekarang ini memperbaiki keyakinannya setelah melihat bangkitnya agama-agama dalam wacana politik lokal atau pun global.Agama sekarang ini juga mempunyai andil yang cukup besar dalam menciptakan perdamaian dunia, pembangunan ekonomi dan hak asasi manusia. Takjarang terjadi pesan keagamaan untuk mendamaikan persoalan konflik yang ada di masyarakat seperti fatwa ulama untuk perdamaian atau juga pesan Paus untuk menghindari kekerasan. Untuk itu lebih lanjut lagi Berger berasumsi bahwa faktor agama berada di balik kejadian di atas.

Kejadian di atas juga seakan-akan mendukung tesis besar Samuel P. Huntington akan terjadinya the clash of civilizations (benturan peradaban). Dahulunya telah terjadi benturan peradaban antara blok Timur dan blokBarat. Blok Timur yang dikenal berpaham komunis secara lembaga diwakili oleh Uni Soviet dan blok Barat yang diwakili oleh negara-negara sekuler seperti Amerika, Inggris dan lain-lain. Namun dengan runtuhnya Uni Soviet akhir tahun 1980-an dan runtuhnya tembok Berlin pada tahun 1989 meninggalkan masalah tersendiri.

Huntington mengingatkan kita bahwa benturan peradaban juga akan terjadi lagi. Dengan membedakan paling sedikit tiga kelompok peradaban yang dapat menjadi tantangan bagi Barat yaitu: Islam-Cina, Afrika-Amerika Latin, dan Jepang-Rusia-India, ia dengan yakin bahwa tantangan paling besar akan dihadapi Barat yaitu dengan kelompok pertama, Islam-Cina. ${ }^{3}$

'Peter. L. Berger, The Desecularization of the World: Resurgent Religion and World Politics, Washington D.C.: Ethics and Public Policy Center, hal. 2-3.

IIbid, hal. 3

${ }^{3}$ Samuel P. Huntington, 1996, The Clash of Civilizations and the Remaking of the World Orde, London: Touchstone Books, hal. 184-5. 
Mungkin pada mulanya orang tak akan menghiraukan tesis Huntington ini bahkan menertawakannya sebagai lelucon namun sekarang bukti-bukti itu telah muncul satu persatu. Barat (seperti Amerika dan negara-negara besar lainnya) mulai membidik Islam sebagai ancaman dan harus diperangi. Islam yang hadir di Barat sering dicitrakan dengan gerakan yang gemar kekerasan dan intoleransi. Masyarakat Islam dianggap sebagai uncivilized community (komunitas yang tak beradab). Peristiwa 11 September, bom Bali dan konflik bernuansa SARA lainnya seakan-akan menjadi legitimasi sikap tersebut. Tentu saja citra ini sangat tidak menguntungkan bagi Islam dan apalagi perkembangan Islam ke depan. Untuk itu, dibutuhkan pemahaman bersama tentang kenyataan yang ada dan juga teologi yang menghargai sesamanya.

\section{Perubahan Zaman, Perubahan Cara Pandang}

Di samping persoalan di atas, konon katanya, saat ini kita sudah berada pada zaman pasca modern (postmodern), yang ini juga membawa persoalan tersendiri. Anggapan ini dapat dilihat buktinya dalam bidang ekonomi, misalnya orang sudah semakin mobile, transportasi semakin lancar, informasi sudah semakin maju yang membawa kita pada era baru yaitu globalisasi. ${ }^{4}$ Jejak (trace) itu juga dapat dilacak dalam bidang pemikiran (terutama filsafat). Modernisme yang mengusung isu-isu besar (grand narrative) seperti kemanusiaan, religi, kebudayaan dan perdamaian ternyata mengalami jalan buntu.

Modernisme yang menelorkan kecanggihan sains dan teknologi di satu sisi sangat menguntungkan yaitu membantu dan mempermudah kegiatan manusia, namun di sisi lain membawa kebangkrutan manusia modern. Memang benar modernisme membawa kita kepada peningkatan akses informasi, menjalarnya ekonomi global dan revolusi teknologi (pembuatan senjata canggih) namun modernisme juga membawa manusia ke jurang yang tanpa batas, manusia menjadi objek, terjadinya konflik dan peperangan yang berkepanjangan dan menjadi koloni bagi yang lain. Dan yang paling parah manusia menciptakan jalan kematiannya sendiri. Sains dan teknologi menjadi postulat dan ideologi yang tertutup. ${ }^{5}$

Kemajuan manusia hanya diukur oleh kemajuan sains dan teknologi bahkan peradaban manusia dibimbing dari sana. Sains menjadi sebuah kontrol teknis (hasil dari rasio atau tindakan teknis) bagi penciptanya sehingga manusia layaknya robot yang dikendalikan oleh hasil ciptaannya sendiri.

${ }^{4}$ Proses globalisasi dapat ditandai dua hal yaitu meningkatnya arus informasi dan lancamya transportasi. Di samping itu, tanda globalisasi sudah muncul sekitar abad 19. Durkheim menyebutkan adanya dua fenomena yang bertentangan, increasing unity dan increasing diversity. Lihat dalam: Lester R.Rutz, 1995, God in the Global Village: The Worlds Religion in Sociological Perspective, California: Piene Forge Press, hal: 5.

${ }^{5}$ Habermas mengkritik keadaan modernisme yang justru membawa kebangkrutan manusia. Lihat lebih jauh: Habermas, 1991, Ilmu dan Tekhnologi Sebagai Ideologi, Jakarta: LP3ES. 
Kemampuan komunikasi manusia untuk mengembangkan dirinya dalam rasio dan tindakan komunikatifseperti kehilangan fungsinya ${ }^{6}$ Agama pun kehilangan maknanya. Kekeringan spiritual (keterikatan pada ilahi) diganti dengan keterikatan pada produk. Persoalan-persoalan inilah yang diidentifikasi oleh para pemikir pasca modernis. Menurutnya orang-orang modern telah terjebak pada cara berfikir yang logosentris, yaitu hanya mematok standar kebenaran dan nilai dengan satu cara: ukuran sainstis dan ilmiah semata.

Pascamodern mempunyai semangat untuk menghargai perbedaan dari semua lini kehidupan baik dalam pengetahuan, agama, kebudayaan, dan seni. Pascamodern juga mempunyai semangat menghancurkan (dekonstruksi) terhadap model-model pengetahuan logosentris, absolutisme, dan pro status quo. Namun bukan berarti bahwa postmodernisme kembali pada konservatisme atau tradisionalisme. Orang boleh saja berprilaku konservatif ataupun tradisional namun yang dilawan oleh postmodermisme adalah pemutlakannya, yang biasa disebut dengan pandangan konservatisme dan tradisionalisme. $^{7}$

Dalam konteks sastra misalnya, terjadi perdebatan yang cukup serius antara orang yang menganggap sastra bersifat universal dengan yang beranggapan kontekstual, dalam seni antara sensasionalitas Inul sebagai representasi dari budaya massa (pop) melawan budaya yang adiluhung dan pluralisme agama menggoyahkan absolutisme dan truth claim yang ada. Semangat inilah yang sudah menggejala dalam dunia kita atau paling tidak dalam pikiran kita. ${ }^{8}$ Pasca modern adalah semangat untuk menegaskan eksistensi dan ke "Ada" an (Being) kita yang selama ini (di dunia modern) teras digerogoti. Pasca modern bersemangat untuk menghargai yang lain (the other) yang selama ini di tindas dan teralienasi oleh absolutisme pengetahuan modern. Berikut ini akan kita lihat bagaimana penegasan itu dilakukan oleh Gadamer dalam prespektif permainannya.

\section{Gadamer dan Perspektif Permainan}

Sudah sejak lama manusia kehilangan ekistensinya. Mulai Descartes yang menyatakan rasio sebagai pusat manusia (Cogito Ergo Sum), hingga Freud yang membagi

${ }^{6} \mathrm{Habermas}$ membagi rasio kedalam dua hàl yaitu rasio tekhnis atau bertujuan yang berfungsi sebagai kontrol tindakan-tindakan tehnis seperti dalam birokrasi dan ilmu alam dan rasio atau tindakan komunikatif yang melakukan tindakan komunikatif. Modernisme terlalu di dominasi oleh rasio tehnis. Lihat, F.Budi Hardiman, 1990, Kritik Ideologi:Pertautan Pengetahuan dan Kepentingan, Yogyakarta: Kanisius, hal. 86-90.

${ }^{7}$ Emmanuel Gerrit Singgih, 2002, Teologi dalam Konteks, Yogyakarta: Duta Wacana University Press, hal: 7.

${ }^{8}$ Perdebatan cukup hangat pernah terjadi antara kedua pendukung kelompok ini. Arif Budiman, Ariel Haryanto dan kawan-kawan pernah melakukan hal yang sama dengan mengetengahkan Perdebatan sastra Kontekstual. Lihat dalam Ariel Haryanto, 1985, Perdebatan Sastra Konstekstual, Jakarta: C.V Rajawali. 
manusia pada unsur kesadaran dan ketidaksadaran. Dari Marx yang menekankan sisi sejarah materialisme hingga khutbah-khutbah Nietzsche yang lantang tentang "kematian tuhan". Sudah sejak lama rasio kita digunakan untuk memperoleh tujuan yang dalam banyak hal tujuan tersebut lebih banyak ditentukan oleh bermacam kepentingan yang justru kadangkala tidak bersifat rasional dan tidak manusiawi (anti humanistik). ${ }^{9}$

Untuk itu, Gadamer menawarkan konsep baru untuk menegaskan kembali eksistensi kita terutama mengahadapi keanekaragaman dan pasar raya perbedaan pasca modern. Dalam filsafat hermeneutiknya, Gadamer menawarkan peralihan konsep dari Aku-Subjek menjadi “Ada" (Being). Peralihan ini ditemukan contohnya dalam sebuah permainan. ${ }^{10}$ Dalam bergumul dengan realitas yang majemukAku-Subjek seakan-akan lenyap namun sebenarnya masih "Ada" dan eksis. KeAku-an kita larut dalam interaksi kita dengan realitas namun sebenamya tetaplah "Ada". Kita seolah-olah sedang dalam permanian besar yaitu realitas.

Kemajemukan mensyaratkan kita untuk melakukan permainan yang mungkin belum pernah kita kenal sama sekali. Dalam permainan ini kita pasti menemukan "the other" yang sangat asing tentunya." "Permainan" ini mengindikasikan beberapa hal. ${ }^{12}$ Pertama, ketergantungan pada realitas di luar dirinya sekaligus ketidaktergantungannya (otonomi). Kedua, permainan bukanlah sekedar aspek kebudayaan semata namun sekaligus sebagai "cara berada" (mode of Being) kita. Ketiga, dalam permainan tidaklah terdapat relasi penguasaan tetapi relasi "belonging" sehingga tidak terdapat dikotomi tragis Kantian yaitu Subjek vs Objek, Nilai vs Fakta dan Manusia vs Dunia. Dengan hilangnya dikotomi ini sekaligus menegaskan otonomi manusia dengan gejala religiusitasnya. Pengalaman religius manusia menjadi lebih bermakna (meaningfull) dan bukanlah sia-sia (meaningless). ${ }^{13}$

244.

${ }^{9}$ I. Bambang Sugiharto, 2000, Wajah Baru Etika dan Agama, Yogyakarta: Kanisius, hal:

${ }^{10}$ Penelitian tentang permaian sebagai bentuk eksistensi manusia dilakukan oleh John Huizinga dengan karyanya Homo Ludens. Hal serupa dilakukan Gadamer untuk menegaskan keAda-an kita didunia. Maksud utamanya sebenarnya adalah sebagai kritik terhadap metode sains yang mencari kebenaran dengan mengambil jarak dari objeknya (ahistoris). Gadamer yakin kebenaran melampui metode. Hal itu ditunjukkan dalam permainan. Lihat dalam; Has George Gadamer, 1975 , Truth and Method, New York: The Seabury Press, hal: 91-119

${ }^{11}$ Istilah the Other dipopulerkan oleh Jaques Derrida bersama istilah deconstruction yang ingin mengubah tatanan yang ada, terutama dalam tatanan ilmu pengetahuan yang dianggap mapan.

${ }^{12}$ I. Bambang Sugiharto, op. cit, hal. 245

${ }^{13}$ Dua istilah ini dikenalkan oleh Wittgeisntein awal dalam TractatusLogico Philosophycus yang menyatakan semua hal harus disa dibuktikan secara empiris (Picture Theory). Namun akhimya Wittgeinstein menyatakan bahwa yang ada sebenarnya adalah language game (permainan bahasa) hal ini dapat dilihat dalam karyanya The Philosophical Investigation. 
Bermain sebagai cara berada kita di dunia (being in the world) menurut Gadamer tidaklah dapat dijelaskan secara gamblang bahkan oleh pemainnya sendiri. Meski si Subjek mengetahui apa itu bermain, namun sebenarnya ia tidak benar-benar tahu kepastian permainannya, yang ada hanya prediksi tentative belaka. Maka bermain bukanlah prilaku tertentu, bukan sebuah pikiran (state of mind) bukan pula kesadaran melainkan lebih dari itu cara berada (mode of being). ${ }^{14}$ Si Subjek larut dalam permainan yang dimainkannya, sehinga yang menjadi subjek bukanlah pemainnya tetapi permainan itu sendiri yang "mewujudkan diri" dalam diri pemain.

Gadamer melacak penggunaan kata bermain secara metaforis dilakukan oleh Buytendijk. Dalam konteks metaforis kata semakin bermakna jika terjadi deviasi. Semakin banyak salah penggunaan, semakin dapat dipahami. Kata-kata seperti permainan cahaya, permainan ombak, permainan kekuatan adalah bermain yang tidak memiliki tujuan akhir. Bermain adalah pementasan gerakan-gerakan yang terlepas dari apa dan siapa yang melakukannya. Permainan dipahami Gadamer sebagai "peristiwa" yang tidak mempunyai tujuan tetapi juga tidak ada upaya. Dalam permainan, manusia hanya mengikuti gerak dan pola permainan yang ada. Maka permaian meskipun serius para pemainnya merasa santai dan ringan, karena ia telah dikuasai oleh permainannya itu. Semakin tinggi resikonya, semakin menenggelamkannya dalam kenikmatan bermain. Setiap permainan (game) mempunyai "ruh" nya sendiri untuk menenggelamkan para pemainnya.

Kalau dalam permainan tujuannya menang kalah, memasukkan gol ke dalam gawang misalnya, itu hanya sebatas tujuan jangka pendek, sedangkan tujuan jangka panjangnya adalah kenikmatan bermain. Maka kita akan jemu melihat dan tidak bersemangat saat melihat permainan yang berat sebelah, satu kelompok terlalu mendominasi (single majority) jalannya permainan tanpa perlawanan yang berarti dari pihak lawan. Keduanya harus seimbang dan fair play. Dalam konteks seni permainan ini dapat dilihat dalam bentuk lukisan. Lukisan akan bermakna (indah) karena ada "deviasi" warna di dalamnya. Bukan warna yang monoton tetapi karena pencampuran warna yang seimbang. Akhirnya lukisan itu bermakna bukan saja pada pelukisnya (yang bermain dengan kuas dan catnya) tetapi juga pada penontonnya.

Permainan bukan saja representasi diri dari pemainnya, tetapi juga representasi dari penontonnya. Penonton ditarik masuk ke dalam permainan, misalnya dengan analisa, kritik, sanjungan dan apresiasi lainnya. Realitas permainan adalah realitas pada dirinya sendiri yang melingkupi subjek penonton. Permainan bermakna bagi penonton lepas dari siapa yang memainkannya. Semua sudah larut dalam permainan. Akhirnya permainan bukan saja cara bereksistensi kita tetapi sekaligus sebagai ke Ada an kita.

${ }^{14}$ Has George Gadamer, op. cit, hal. 92. 


\section{E. Pluralitas Agama Sebagai Bentuk Permainan}

Secara arkeologis, kemajemukan (pluralitas agama) sudah ada sejak lama dalam sejarah Indonesia. ${ }^{15} \mathrm{Kita}$ sudah mengenal beragamnya agama pribumi (indegenius religion), misalnya banyaknya kepercayaan, yang kemudian dikategorikan secara dualistik: animisme dan dinamisme, ditambah lagi dengan kehadiran agama resmi (official religion), Hindu, Budha, Katholik, Kristen, dan Islam. Dengan keadaan yang majemuk ini (plural) kita dipaksa untuk bersikap. Perkembangan sains dan teknologi membawa kita pada era globalisasi yang tak terelakkan. Dunia menjadi semakin kecil, yang membawa kita pada interaksi satu sama lain, termasuk interaksi antaragama. Dunia juga sudah semakin transparan. Garis demarkasi seperti etnisitas, budaya, religi, dan Negara seakanakan sudah hilang.

Kemajemukan ini menuntut kita untuk mengenal satu sama lain. Isolasi dan apatisme justru akan membatasi aktualisasi dan representasi diri di hadapan the Other. Eksistensi dan ke Ada an kita bisa tetap terjaga karena kehadiran orang lain. Pluralitas mengajak kita untuk sama-sama bermain dengan kemajemukan yang ada. Kenyataan yang kita hadapi (termasuk dalam agama) bukanlah kenyataan yang sudah jadi (being) melainkan kenyataan yang harus dipahami sebagai proses "menjadi" (becoming). Maka kenyataan adalah proses perubahan yang terus menerus. Darwin pernah menyatakan bahwa "penciptaan" adalah peristiwa yang bukan sekali jadi, melainkan proses yang berjalan terus menerus hingga kini. Proses perubahan (menjadi) ini membawa kita pada permainan yang tak pernah usai, senantiasa ada perubahan-perubahan pola permainan. Pluralisme membawa kita untuk melakukan permainan di berbagai tempat dan bukan monoton satu tempat saja (absolutisme).

Untuk itu perlu dirumuskan suatu tatanan kehidupan ke depan yang menghargai sesama manusia meski berlainan keyakinan dan agama. Perlu dihadirkan sebuah teologi agama yang menghargai sesama manusia. Untuk itu perlu adanya teologi kontekstual yang bersumber dari realitas kehidupan yang dialami masing-masing pemeluk agama. Teologi yang memperhatikan perubahan sosial keagamaan dan kebudayaan dimana komunitas beragama itu berada. Kita mungkin tidak asing dengan istilah black teology (teologi hitam) yang muncul di kalangan orang kulit hitam atau liberation theology (teologi pembebasan) seperti yang lahir di Amerika Latin. Teologi ini muncul sebagai hasil interaksi dengan kebudayaan setempat. Untuk itu keberagaman bentuk teologi sebagai sesuatu yang tak terelakkan karena selalu berinteraksi dengan keberagaman kebudayaan yang ada. Karena kebudayaan menurut Geertz memiliki seperangkat nilai dan makna yang

${ }^{15}$ Metode arkeologi adalah usaha untuk menganalis sejarah perkembangan peradaban dan ilmu pengetahuan serta sumber episteme nya masing-masing yang berkembang di Eropa yang pernah dilakukan Foucault, Lihat: Michel Foucault, The Order of Things: an Archeology of Human Sciences, New York: Vintage Books, hal xiv. 
memberi petunjuk untuk hïup. Kèbudayaan bukanlah sesuatu yang berada di luar seseorang, melainkan berada dan manusia terlibat di dalamnya. Untuk itu, teologi juga harus berada di dalam konteks dimana manusia beragama itu berada. ${ }^{16}$

Harus diakui bahwa religion way of knowing (cara pandang agama) sangatlah mempengaruhi aktifitas keagamaan kita. Teologi sebagai cara pandang agama sebenamya telah hadir di kehidupan kita. ${ }^{17}$ Cara pandang eksklusif misalnya, berpandangan bahwa kebenaran dan keselamatan hanya pada agama dan keyakinannya sendiri dan tidak akan ditemukan pada agama orang lain. Sementara sikap inklusifberpandangan, bahwa kebenaran dan keselamatan terdapat juga pada agama dan keyakinan orang lain. Sikap ini kelihatan lebih terbuka dibanding sikap yang pertama, namun pada dasarnya tidaklah demikian, karena kebenaran yang lain juga itu terjadi karena cara pandang yang dipakainya adalah cara pandang kebenaran sendiri juga. Sehingga pada akhirnya sikap yang kedua ini tidak berbeda dengan cara pandang yang pertama.

Sementara itu, cara pandang pluralis beranggapan, bahwa pada dasarnya semua agama memiliki kebenaran dan keselamatan, itu hanya karena kebudayaan dan konteks mereka yang berbeda-beda maka terjadilah perbedaan pemahaman akan kebenaran dan keselamatan itu. Untuk itu, tidak ada yang dapat mengklaim bahwa agamanya sendirilah yang paling benar. Sikap ketiga ini kalau kita teliti akan menimbulkan masalah tersendiri. Kalau setiap orang bersikap demikian maka orang tersebut tidak akan peduli dengan yang lainnya, karena kebenaran dan keselamatan itu sudah terdapat di manamana. Akhirnya akan lahir sikap apatis kepada orang lain. Pada akhirnya sikap ini juga tidak berbeda dari sikap yang pertama dan kedua di atas.

Untuk itu John Cobb Jr. menegaskan perlu tambahan sikap yang lain yaitu transformatif. Maka perlu adanya transformasi pemahaman yang kreatif (creative transformation) yang terjadi dalam setiap interaksi dengan orang lain. ${ }^{18}$ Dengan berbekal sikap inklusif yang cocok digabungkan dengan transformatif(inklusif-transformatif) yaitu bahwa kebenaran juga ada di agama dan keyakinan orang lain maka setiap interaksi kita hari ini akan memberikan transformasi pemahaman baru untuk interaksi selanjutnya. Sehingga yang terjadi adalah munculnya pemahaman yang terus baru ketika menghadapi orang lain seiring dengan bertambahnya interaksi kita dengan kehidupan sosial dan konteks dimana kita berada. Mutual understanding pun akan terjadi. Karena kehidupan ini adalah suatu proses kreatif yang terus menerus yang takkan pernah terhenti.

Basic Cook.

${ }^{16}$ Lebih lanjut lihat dalam: Clifford Geertz, 1973, The Interpretation of Culture, New York:

${ }^{17} \mathrm{John}$ A. Titaley, 2001, Menuju Teologi Agama-agama yang Kontekstual, Salatiga: Fakultas Teologi Universitas Kristen Satya Wacana Press, hal: 8-9.

${ }_{11}^{18} \mathrm{John}$ B. Cobb, Jr., 1999, Transforming Christianity and the World: A Way beyond Absölutism and Rialativism. Edited and Introduced by Paul B. Knitter, Maryknoll, New York: Orbis Book, hal: $47-48$. 


\section{F. Penutup}

Konsekuensi dari semakin banyaknya permainan yang kita lakukan, maka terjadi proses melemahnya individualisasi dan semakin meningkatnya proses personalisasi. Artinya, individu-individu menemukan autentisitasnya justru karena keterikatan pada orang lain (the other). Seolah-olah kita lenyap bergumul dengan realitas namun sebenarnya kita justru menegaskannya. Terjadi hubungan ketergantungan, atau interdependensi yang kuat satu sama lain.

Dua kategori ini bukanlah relasi menang kalah atau relasi penguasaan, namun lebih tepat disebut dengan relasi belonging. Dua-duanya membutuhkan satu sama lain. Proses yang sama juga terjadi pada bidang religius. Globalisasi membawa kita untuk saling berhadapan satu sama lain. Komunitas agama tertentu berhadapan dengan komunitas agama lain. Permainan yang dilakukan adalah adanya saling penghargaan satu sama lain bukan persoalan dominasi dan hegemoni. Kenikmatan hubungan intim ini bisa dilakukan dengan cara melakukan dialog bersama-sama tanpa ada tekanan. Munculnya fakta yang banyak berbeda dengan kita justru menarik kita untuk masuk ke dalamnya dan menyatu dalam permainan-permainannya. Sementara kita larut di dalamnya, justru akan menegaskan kita dengan membawa pengalaman dan pengetahuan (insight) baru tentang kita sendiri dan kenyataan.

Dengan niat yang tulus dan tindakan yang komunikatif untuk mengenal diri orang lain yang secara bersamaan mengenal diri kita sendiri maka bukanlah mustahil persoalan yang dihadapi dapat diselesaikan bersama-sama secara tuntas dengan konsensus yang dihasilkan tanpa paksaan. Marilah kita mulai bermain untuk mengenali orang lain dan diri kita sendiri. Mengenal orang lain bukanlah berarti mesti mengikuti tindakannya tetapi bisa mempengaruhi ataupun dipengaruhi, maka dibutuhkan sikap kritis dan inovatif. Bukankah hidup ini hanyalah permainan dan senda gurau? 


\section{DAFTAR PUSTAKA}

Berger, Peter. L., The Desecularization of the World: Resurgent Religion and World Politics, Washington D.C: Ethics and Public Policy Center.

Cobb, John B., 1999, Transforming Christianity and the World: A Way beyond Absolutism and Relativism. Edited and Introduced by Paul B. Knitter, Maryknoll, New York: Orbis Book.

Foucault, Michel, The Order of Things: an Archeology of Human Sciences, New York: Vintage Books.

Gadamer, Has George, 1975, Truth and Method, New York: The Seabury Press.

Geertz, Clifford, 1973, The Interpretation of Culture, New York: Basic Cook.

Habermas, 1991, Ilmu dan Tekhnologi Sebagai Ideologi, Jakarta: LP3ES.

Hardiman, F. Budi, 1990, Kritik Ideologi:Pertautan Pengetahuan dan Kepentingan, Yogyakarta: Kanisius.

Haryanto, Ariel, 1985, Perdebatan Sastra Konstekstual, Jakarta: C.V Rajawali.

Huntington, Samuel P., 1996, The Clash of Civilizations and the Remaking of the World Orde, London: Touchstone Books.

Rutz, Lester R., 1995, Godin the Global Village: The Worlds Religion in Sociological Perspective, California: Piene Forge Press.

Singgih, Emmanuel Gerrit, 2002, Teologi dalam Konteks, Yogyakarta: Duta Wacana University Press.

Sugiharto, I. Bambang, 2000, Wajah Baru Etika dan Agama, Yogyakarta: Kanisius.

Titaley, John A., 2001, Menuju Teologi Agama-agama yang Kontekstual, Salatiga: Fakultas Teologi Universitas Kristen Satya Wacana Press. 